EUROPEAN HONORS COUNCIL

Note

\title{
Introducing the Journal of the European Honors Council
}

\author{
Marca Wolfensberger ${ }^{1}$, Astrid Fritz ${ }^{2}$, Maarten Hogenstijn ${ }^{3}$
}

1. President, European Honors Council; Hanze University of Applied Sciences, The Netherlands; Utrecht University, The Netherlands

2. Research Commissioner, European Honors Council Board; Austrian Research and Support Centre for the Gifted and Talented (OEZBF), Austria

3. Secretary, European Honors Council; Hanze University of Applied Sciences, The Netherlands

Correspondence: info@honorscouncil.eu

Published: 5 May 2017

The Board of the European Honors Council is honored to present the inaugural issue of the Journal of the European Honors Council. With this Journal, we aim to share knowledge and good practices regarding honors programs and talent development programs in higher education around Europe. To facilitate this exchange, we proudly publish this journal in full open access. In this short introduction we present the scope of the Journal, relating this to the general aims of the European Honors Council.

\section{Background}

How can we help talented young people to reach their full potential and equip them for a future where they can solve societal problems? This is the main question that started the founding process of the European Honors Council (EHC), a new European network around the subject of talent development in European higher education. The EHC was opened for membership in 2016 to stimulate talent development programs at European Higher Education Institutions (HEIs). The network brings together people who are involved in or interested in offering special programs for talented students in higher education (often known as honors programs). As the term 'honors programs' is not yet fully established in Europe, we could also indicate them as talent development programs in higher education.

In the EHC, we work with the following definition: 'Honors programs are selective study programs linked to higher education institutions. They are designed for motivated and gifted students who want to do more than the regular program offers. These programs have clear admission criteria and clear goals and offer educational opportunities that are more challenging and demanding than regular programs' (Wolfensberger, 2015, p. 12).

Even though there is plenty of knowledge on this issue around Europe and beyond, there is an apparent lack of knowledge exchange between European HEls. Solving this 'information 
gap' has been a driving force in founding the EHC. The urgency of this issue is linked to the realization that Europe is facing an increasing number of multi-faceted problems. The young people of today will have to lead the way in facing and solving the challenges of tomorrow. But in our current education system, many talented and motivated students are not sufficiently challenged and supported.

\section{Founding process}

The European Honors Council was formed following the first results of the research project Honors in Europe, led by Marca Wolfensberger at Hanze University of Applied Sciences Groningen, the Netherlands.

In this project, the first-ever inventory of honors programs and the national culture towards excellence in eleven northern European countries was compiled. This led to the book Talent Development in European Higher Education: Honors Programs in the Benelux, Nordic and German-speaking countries (Wolfensberger, 2015). The book was published in open access at the publisher Springer and has been downloaded over 50,000 times in the two years since its publication.

In the research for this book, it turned out that people involved in honors and talent development were very eager to get to know colleagues working on the same subjects in other countries. However, there was no structure of any kind to support this kind of exchange. Therefore Marca Wolfensberger joined up with Ron Weerheijm (Rotterdam UAS). They decided to invite a select group of key persons to a conference in June 2015, to discuss possibilities of formation of a European network. The idea was met with great enthusiasm and immediately afterwards, a steering committee for the European network-to-be was formed. The European Honors Council was created. The EHC was launched officially on June 3rd, 2016.

\section{Network goals}

In the year following the first meeting, the committee's ten members agreed on ten network goals (European Honors Council, 2016).

1. Supporting and stimulating development of honors education and its structural embeddedness in the education system

2. Creating a common language

3. Supporting teacher professionalization (within honors)

4. Creation and exchange of knowledge about honors programs

5. Stimulating and facilitating research about honors

6. Enabling networking for people involved in honors

7. Stimulating spin-off of successful honors practices to regular education

8. Promoting an easier flow of talented students from secondary to higher education

9. Stimulating professional development of honors students and connection to working life / research career

10. Stimulating collaboration and inspiring student exchange at honors level

These goals are all related to four main themes: education, research, student affairs and/or international affairs. Therefore the EHC set up committees on these themes, which further 
pursue the network goals related to their subject. At the international conference 'Honours Futures' in Utrecht in June 2016 (an event on the official agenda of the Dutch EU Presidency) the EHC was officially introduced and opened for individual membership. The steering group was turned into an acting board.

\section{Added value and plans}

The added value of the European Honors Council compared to existing networks is evident in two main distinguishing features:

- The focus of this network on talent development and honors in higher education (including the links from secondary to higher education and from higher education to working life / Ph.D)

- $\quad$ The focus on programs that are designed for students who can and want to do more than the regular program offers (not necessarily gifted individuals).

For its members, the EHC offers opportunities for the exchange of knowledge and good practices, new insights, possibilities for student and teacher exchange at honors level, joint research projects and a platform to support the development of honors programs in national education systems and their structural embeddedness. At this stage, membership is free and open to all involved in honors education.

Prospective members can visit the EHC website and fill in the membership questionnaire, providing the EHC with basic information personal and institutional information, as well as information on honors programs one is involved in or plans to be involved in. The EHC asks members to share this pivotal information with other members. In order to create a dynamic network, in which more and more people will reach out to each other. We agree with Lovink (2011) that 'in the information age, networking is key. Network cultures are here to stay. However self-evident it is, collaboration is a foundation of network cultures.' All members are inscribed on the EHC mailing list and kept up-to-date on EHC activities and other relevant information regarding their chosen committee(s).

\section{The Journal}

The European Honors Council is a work in progress and maybe always will be - just like honors education. Establishing the Journal of the European Honors Council is an important milestone. This allows the sharing of research results on honors education, as well as good practices. It also helps to create a common knowledge base. Therefore we chose deliberately to publish in open access, so all interested educators and stakeholders can take advantage of findings published in the Journal. This also means that we can publish relatively fast to share new results and good practices with our audience.

You are very welcome to submit your work to the Journal of European Honors Council (JEHC). The JEHC has an editorial policy for two kinds of publications: a blind peer-review process for longer scholarly articles on honors education (papers) and a review system for shorter notes. More information can be found in the guidelines for authors on the website.

The Editorial Board's introduction (note 2) will delve deeper into the contents of this inaugural issue. We hope you find the Journal as valuable as we do and look forward to receiving your contributions. 
On behalf of the Board of the European Honors Council,

Dr. Marca Wolfensberger, President

Dr. Astrid Fritz, Research Commissioner

Dr. Maarten Hogenstijn, Secretary

\section{References}

European Honors Council (2016). Aims of the European Honors Council. http://honorscouncil.eu/aims.html

Lovink, G. (2011). Networks without a cause: A critique of social media. Polity Press

Wolfensberger, M.V.C. (2015). Talent development in European higher education. Honors Programs in the Benelux, Nordic and German-Speaking Countries. Heidelberg: Springer. http://link.springer.com/book/10.1007\%2F978-3-319-12919-8 